\title{
SMEs Management Success Determinants and its Implications on Their Performance in South West, Nigeria
}

\author{
Submitted 09/10/20, 1 st revision 27/11/20, 2nd revision 09/12/20, accepted 20/12/20
}

\author{
Olalekan Asikhia $^{1}$, Vannie Naidoo ${ }^{2}$
}

\begin{abstract}
:
Purpose: In developing nations, like Nigeria, Small and Medium scale Enterprise (SME) is supposed to be a catalyst for socio-economic development and employment generation. Eighty-five percent of the SMEs failed before their fifth anniversary. The study undertook to identify influential management success determinants and the concomitant effects on SMEs' performance in Nigerian unstable business environment.

Approach/Methodology/Design: The study used a cross sectional survey research design and probability sampling methods of stratified, random and proportional samplingto select 1102 CEOs. There were 988 completed questionnairesreceived back from respondents, giving and excellent response rate of $89.66 \%$.

Findings: The result of the study revealed significant difference in the evaluations of management success determinants to performance and management skills of the SMEs operators, organizational structure and innovation as being the most critical success factors for the SMEs in the Nigerian business environment. The most significant individual effects on SMEs performance are traceable to organizational structure, management skills and environmental scanning. There is a combined strong effect of the management success determinants on SMEs performance.

Practical Implications: Apart from contributing to the existing literature on SMEs performance, the study also noted that new entrants into Nigerian market environment will succeed if the right organizational structure is put in place and innovation as well as management skills are taken seriously.

Originality/Value: This study contributes by discovering that management skills of the SMEs operators, organizational structure and innovation are the most critical success factors for the SMEs in the Nigerian business environment.
\end{abstract}

Keywords: Management success determinants, Performance, Small and Medium Scale Enterprises (SMEs), South West Nigeria.

Paper Type: Research Paper

Acknowledgements: We would like to thank all that participated in the survey. We would like to acknowledge the Small and Medium Enterprise Development Agency of Nigeria (SMEDAN).

${ }^{1}$ University of KwaZulu- Natal, University of KZN Durban 4041

South Africa, E-mail: olalekanasikhia@yahoo.com;

${ }^{2}$ University of KwaZulu-Natal, University of KZN Durban 4041

South Africa, E-mail: naidoova@ukzn.ac.za; 


\section{Introduction}

The management issues of the SMEs have been unfavourably affected by the dynamism of the business environment in which they operate, (Adeola, 2016; Fernando, 2011). This is particularly so, with the uncontrollable Nigerian market environment. Recent closures of several SMEs in the Nigerian economy have been adduced to the unfavourable environment of some businesses and attendant effects of unstable government policies (Adeola, 2016; Umeofia, 2016).

In a developing nation, like Nigeria, Small and Medium scale Enterprise (SME) is supposed to be a catalyst for socio-economic development and a veritable tool for employment generation, however, the situation is on the contrary. Akinbogun (2008) noted that eighty five percent of the SMEs failed before their fifth anniversary, and that assertion was corroborated by the Small and Medium scale Enterprises' Development Agency of Nigeria studies (SMEDAN, 2012; 2016).

Some researchers have noted that effective management of SMEs' operations could help in alleviating the major problems that are often being faced. Serrasqueiro et al. (2018) identified some critical capabilities in the area of cost estimation, environmental scanning, assessment, and predictions, work definitions, clients' criteria as well as work objectives as the major variables of success. Others are; prompt product/service delivery Bocconcelli et al. (2018) management knowledge and skills, business processes, evaluation of performance, business structure and systems (Ahmed et al., 2018; Wang and Zhou, 2019) business plan, (Arasa and K'Obonyo, 2012; Forth and Bryson, 2019; Ighodalo et al., 2019) managerial attitude and practices (Asikhia, 2010; Okwachi et al., 2013; Sabli and Latiff, 2019), strategy (Maney et al., 2014; Rizan, Balfas, and Purwohedi, 2019) and marketing (Omar and Anas, 2014; Van Scheers, 2011).

It is against this backdrop that this research intends to establish the management success' determinants of SMEs in Southwest Nigerian markets of Lagos, Ogun and Oyo States, the nerve centres of businesses with high concentration of SMEs in Nigeria.

\section{Literature Review and Hypotheses Development}

Management success determinants have been established to affect SMEs performance in different ways. For example operators' experiences have been shown in different researches to affect performance of companies. Takeuchi et al. (2019) divided work experience into three categories job experience, organisational experience, and international experience, they affirmed these three are needed for effective performance depending on the operational context of the company.

Further more, Whitler et al. (2018) established that experience of board members facilitates firm growth. They particularly noted that experienced marketing board 
members help firms prioritise growth as strategy objective and improve effectiveness of revenues growth strategies. Connelly et al. (2018) asserted competence and integrity-based trust, as management experience affect transaction costs in a company. They affirmed that integrity-based trust is more potent than competence-based trust in reducing transaction cost. It is thus hypothesized that:

$H_{1}$ : There are significant differences in the evaluations/experience of SMEs operators of the managementsuccess determinants with respect to marketing ability, managementskills, innovation, decision making process, operating system, organizational structure, business reporting system, system flexibility and environmental scanning to performance.

Several researchers have noted that some management success determinants either positively or negatively related to performance depending on the context (Aminu and Shariff, 2015; Muthe and Aksoy, 2014; SMEDAN, 2012). Akinruwa et al. (2013), however, identified that management skills, government policy, education and infrastructural support related positively with SMEs performance in the Ekiti state, South Western Nigeria. This was corroborated by Osamwonyi (2010) and Olabisi et al. (2011), in their different studies. Heyden et al. (2018) affirmed that management structure, processes and practices improve organisations' performances. It is thus hypothesized that:

$\mathrm{H}_{2}$ : Management success determinants will have significant relationships with SMEs Performance.

$\mathrm{H}_{3}$ : Management success determinants will have relative significant effects on SMEs Performance.

$H_{4}$ : Management success determinants will have combined significant effects on SMEs Performance.

\section{Research Methodology}

This is a quantitative study of survey research design to elicit reliable information and generate numeric data on the variables of the study because it produces data based on real-world observations apart from its breadth of coverage and ability to produce a representative sample whose responses can be generalised to the whole population (Asikhia, 2016). The internal validity of the research design was premised on temporal precedence and co-variation of the cause and effects of the variables while the external validity was done through the sampling model; by ensuring that the sample was a good representative of the population, in addition to been validated by SMEs scholars and practitioners. This study was conducted with full compliance to research ethics, norms, and specifically, the codes of practice established by University of KwaZulu Natal Research Ethics Committee.

\section{Target Population:}

The population of the study comprised the CEOs of the registered small and medium scale businesses with maximum asset base of N200 million, excluding land and 
working capital, and 10 to 300 employees in the selected South Western Nigerian market of Lagos, Ogun and Oyo states; these were states with the highest number of functional SMEs in Nigeria whose number stood at 21, 444 as at February 2017 (Corporate Affairs Commission, CAC, 2017).

\section{Sampling Frame:}

The sampling frame was drawn from the SMEDAN that has a comprehensive list of the registered SMEs with the Corporate Affairs Commission in Nigeria (CAC Business Directory, 2017; SMEDAN, 2017).

\section{Sample Size Determination:}

The sample size was calculated using the Krejcie and Morgan (1970)'s Table. This is a scientific table that suggests optimal sample size given a population size, specific margin of error and a desired confidence interval. It minimises errors and bias in sample size determination as against determination through the rule of thumb. An adequate sample size of 760 was arrived at, at 3.50 margin of error and $95 \%$ confidence level, however $45 \%$ of it was added to make room for non-response rate typical of the SMEs researches in Nigeria (Asikhia, 2016; Eniola and Ektebang, 2015; Muritala et al., 2012; Olughor, 2015).

\section{Sampling Method:}

Probability sampling methods of stratified, proportionate and random sampling were employed for this study. Firstly, stratified sampling method was used to divide the population into different strata by states and Industries. Secondly, proportionate sampling method was used to know the number of SMEs to be contained in each stratum in the proportion of what is present in the population. Finally, the sample size was selected through random sampling from each stratum in the proportion of what was present in the population, These probability sampling methods have the advantage of reducing bias due to selection because every member of the population had equal chances of being selected (Cooper and Schindler, 2006; Kothari, 2004), all population and corresponding sample size by states is noted in Table 1.

Table 1. Proportionate Sample size distribution by States

\begin{tabular}{|l|l|l|l|l|}
\hline S/N & STATES & $\begin{array}{l}\text { SMEs } \\
\text { POPULATION }\end{array}$ & PROPORTION & $\begin{array}{l}\text { SAMPLE } \\
\text { SIZE }\end{array}$ \\
\hline 1. & Lagos & 11,663 & 0.54 & 600 \\
\hline 2. & Ogun & 1794 & 0.08 & 92 \\
\hline 3. & Oyo & 7987 & 0.37 & 410 \\
\hline & TOTAL & 21,444 & 1.00 & 1102 \\
\hline
\end{tabular}

Source: Researcher's computational result fromCAC Business Directory, 2017; SMEDAN and National Business Statistics Collaborative Survey, 2017).

\section{Data Collection Methods:}

Responses were collected through questionnaires with a predetermined set of questions. The questionnaire was self-administered. The method reduced costs, increased timeliness and improved data quality (Bhattacherjee, 2012; Cooper and 
Schindler, 2006). The researcher was assisted by research fieldworkers familiar with the sample frame, and adequate training was provided to enable them cope with other technical demands of the work. The average time for filling the questionnaire was between 20 to 25 minutes.

The research instrument was a questionnaire consisting of four major sections. The four major sections are; Firstly, biographic details of the companies. Secondly, Management Success Determinants (DMS). Finally, SMEs Performance. All the variables were measured on a five-point scale of likert type. This made it possible to quantify the responses, and compute for statistical analysis, as respondents easily understood them, and it was easy to draw conclusions, reports and results from the responses.

\section{Validity and Reliability:}

A pilot study was conducted to check clarity of the instruments to remove ambiguity and improve the degree of understanding of the instrument by the respondents. The questionnaire was refined by removing areas of misunderstanding. The reliability coefficient was noted by the Cronbach's alpha and the Cronbach'salpha value for the overall data was 0.94 for management success determinants and 0.88 for SMEs Performance. These show that the data were reliable.

\section{Methods of Data Analysis:}

Quantitative method of data analysis was used. It has the advantage of providing accurate results about a phenomenon or a set of activities and facilitates easy hypotheses testing by ensuring easy development of models and theories from empirical data (Forth and Bryson, 2019) Responses were collated, coded and summed up for each of the variables and for each of the participants. The relationships between the variables were measured using product moment correlation coefficient and the combined effect was measured using simple regression analysis. The hypotheses were tested accordingly.

\section{Findings}

One thousand one hundred and two copies of questionnaires were administered to the owners/managers of selected small and medium scale enterprises in Lagos, Ogun and Oyo states of South Western, Nigeria with the intention of ensuring that the sample size would be achieved. Nine hundred and eighty-eight copies of questionnaires were correctly completed and returned, and this represents a response rate of $89.66 \%$ while 114 representing $10.34 \%$ of the questionnaire were either not returned or not correctly completed.

\subsection{Discussion of Hypotheses}

To undertake inferential analysis, the scores of the variables for each respondent were added to obtain overall scores for each of the variables. And the scores were tested for normality and found to be normally distributed hence product moment 
correlation coefficient, difference of mean test and regression analysis were used to test the hypotheses.

$H_{1}$ : There is significant difference in the evaluations of SMEs operators of the management success determinants with respect to marketing ability, operators' experience, management, skills, innovation, decision making process, operating system, organizational structure, business reporting system, system flexibility and environmental scanning to performance.

Table 2 shows the result obtained concerning the first hypothesis.

Table 2. Difference in evaluations of the SMEs Operators of management success determinants

\begin{tabular}{|l|l|l|l|l|}
\hline & $\mathrm{N}$ & Sum & Mean & Std. Deviation \\
\hline Marketing Abilities & 988 & 9565 & 9.68 & 1.66 \\
\hline Operator's Experience & 988 & 9375 & 9.49 & 1.80 \\
\hline Management Skill & 988 & 21398 & 21.66 & 3.05 \\
\hline Innovation & 988 & 15145 & 15.33 & 3.11 \\
\hline Decision Making Process & 988 & 17662 & 17.88 & 2.90 \\
\hline Operating System & 988 & 11083 & 11.22 & 1.68 \\
\hline Organisational Structure & 988 & 17724 & 17.94 & 2.67 \\
\hline Business Reporting System & 988 & 12706 & 12.86 & 2.53 \\
\hline System Flexibility & 988 & 15793 & 15.98 & 2.18 \\
\hline Environmental Scanning & 988 & 11439 & 11.58 & 1.68 \\
\hline Management Success Determinants & 988 & 14189 & 143.61 & 15.48 \\
\hline
\end{tabular}

Source: Authors' computation with the use of SPSS version 20.

The management determinant with the highest mean value is management skill with 21.66, then organisational structure with 17.94 and closing followed by decision making process. The standard deviation, however, from the mean of the experiences of the SMEs operators is highest in innovation (3.11) meaning the experiences of the SMEs operators from one to another greatly differ. The same trend is witnessed in the management skill (3.05). The lowest deviation (1.66) from the mean is witnessed in marketing abilities of the operators with relatively low mean of 9.68. Table 3 shows that the variations/difference in evaluations of management success determinants and SMEs performance are statistically significant $\mathrm{F}(10,978)=174.93$ and $p<0.05$

Table 3. Analysis of Variance of Management success determinants and SMEs performance

\begin{tabular}{|l|l|l|l|l|l|l|}
\hline \multicolumn{2}{|l|}{ ANOVA $^{\text {a }}$ Model } & $\begin{array}{l}\text { Sum of } \\
\text { Squares }\end{array}$ & df & $\begin{array}{l}\text { Mean } \\
\text { Square }\end{array}$ & F & $P$ \\
\hline \multirow{2}{*}{1} & Regression & 29664.52 & 10 & 2966.45 & 174.93 & $.000^{\mathrm{b}}$ \\
\cline { 2 - 8 } & Residual & 16568.22 & 978 & 16.96 & & \\
\cline { 2 - 8 } & Total & 46232.73 & 988 & & & \\
\hline
\end{tabular}


a. Dependent Variable: SMEs Performance

b. Predictors: (Constant), Environmental Scanning, Marketing Abilities, System Flexibility, Operator's Experience, Operating System, Organisational Structure, Decision Making Process, Business Reporting System, Management Skill, Innovation

Source: Field Survey Results.

$\mathrm{H}_{2}$ : Management success determinants will have significant relationships with SMEs Performance.

Table 4 shows that all the management success determinants relate significantly at 0.05 and 0.01 levels of significance with SMEs performance. Management skills of the SMEs operators, however, relate most with performance $(\mathrm{r}=0.60)$ and the correlation coefficient is significant at 0.05 and 0.01 levels of significance. This is followed by organizational structure $(r=0.58)$ and innovation $(r=0.57)$. These relationships show that the skills of the operators which could be the reason for the relatedness of innovation with performance is important in SMEs survival in Nigeria. The fact that a formal structure relates well with the performance also shows that the Nigerian SMEs cannot afford to overlook it, and that structure which helps in information flow and dissemination of decision is critical in Nigerian SMEs, the emphasis on unstructured SMEs does not hold for performance in Nigerian market environment. Business reporting $(r=0.55)$ and operating system $(0.50)$ relate well with performance.

Table 4. Relationship between the management success determinants and SMEs Performance

\begin{tabular}{|c|c|c|}
\hline & & $\begin{array}{l}\text { SMEs } \\
\text { Performance }\end{array}$ \\
\hline \multirow{3}{*}{$\begin{array}{l}\text { Marketing } \\
\text { Abilities }\end{array}$} & Pearson Correlation & $.42^{* *}$ \\
\hline & Sig. (2-tailed) & .00 \\
\hline & $\mathrm{N}$ & 988 \\
\hline \multirow{3}{*}{$\begin{array}{l}\text { Management } \\
\text { Skill }\end{array}$} & Pearson Correlation & $.59^{* *}$ \\
\hline & Sig. (2-tailed) & .00 \\
\hline & $\mathrm{N}$ & 988 \\
\hline \multirow[t]{3}{*}{ Innovation } & Pearson Correlation & $.57^{* *}$ \\
\hline & Sig. (2-tailed) & .00 \\
\hline & $\mathrm{N}$ & 988 \\
\hline \multirow{3}{*}{$\begin{array}{l}\text { Decision } \\
\text { Making Process }\end{array}$} & Pearson Correlation & $.49^{* *}$ \\
\hline & Sig. (2-tailed) & .00 \\
\hline & $\mathrm{N}$ & 988 \\
\hline \multirow{3}{*}{$\begin{array}{l}\text { Operating } \\
\text { System }\end{array}$} & Pearson Correlation & $.50^{* * *}$ \\
\hline & Sig. (2-tailed) & .00 \\
\hline & $\mathrm{N}$ & 988 \\
\hline \multirow{3}{*}{$\begin{array}{l}\text { Organisational } \\
\text { Structure }\end{array}$} & Pearson Correlation & $.58^{* *}$ \\
\hline & Sig. (2-tailed) & .00 \\
\hline & $\mathrm{N}$ & 988 \\
\hline \multirow{2}{*}{$\begin{array}{l}\text { Business } \\
\text { Reporting }\end{array}$} & Pearson Correlation & $.55^{* *}$ \\
\hline & Sig. (2-tailed) & .00 \\
\hline
\end{tabular}




\begin{tabular}{|c|c|c|}
\hline System & $\mathrm{N}$ & 988 \\
\hline \multirow{3}{*}{$\begin{array}{l}\text { System } \\
\text { Flexibility }\end{array}$} & Pearson Correlation & $.40^{* *}$ \\
\hline & Sig. (2-tailed) & .00 \\
\hline & $\mathrm{N}$ & 988 \\
\hline \multirow{3}{*}{$\begin{array}{l}\text { Environmental } \\
\text { Scanning }\end{array}$} & Pearson Correlation & $.49^{* *}$ \\
\hline & Sig. (2-tailed) & .00 \\
\hline & $\mathrm{N}$ & 988 \\
\hline
\end{tabular}

Note: $* *$ Correlation is significant at the 0.01 level (2-tailed), * Correlation is significant at the 0.05 level (2-tailed).

Sources: Authors' computation with the use of SPSS version 20 (2018).

This infers that an organisational system that emphasizes a reporting and definite operational system is important for success. The knowledge of the environment in terms of environmental scanning (0.49) reflects its relevance in system flexibility (0.40) which also facilitates performance.

$H_{3}$ : Management success determinants will have relative significant effects on SMEs Performance.

The individual effects of the management success determinants as shown in table 8 , marketing abilities/skills $(\beta=0.10$ and $\rho=0.05)$, operator's experience, Marketing abilities: $\beta=0.13, \mathrm{P}<0.05$; the effect on SMEs' performance is significant, operators' experience; $\beta=0.19$ and $\mathrm{P}=0.05$; the effect is significant, management skills; $\beta=0.14, \mathrm{P}<0.05$; the effect is significant Innovation $\beta=0.06, \mathrm{P}<0.05$; the effect is significant, Decision making process, 0.05 and $\mathrm{P}=0.05$, the effect is significant, operating system; $\beta=0.09$ and $\mathrm{P}<0.05$; organizational structure; $\beta=$ 0.27 and $P<0.05$, the effect is significant, business reporting system; $\beta=0.10$ and $P$ $<0.05$; the effect is significant; system flexibility; $\beta=0.11$ and $\mathrm{P}<0.05$; environmental scanning practice; $\beta=0.12$ and $\mathrm{P}<0.05$, the effect on SMEs performance is significant. The highest effect is by organizational structure $(\beta=$ $0.27)$, then management skill $(\beta=0.14)$.

The interpretation for organizational structure is one-unit change in organizational structure caused by 0.27 unit of SMEs performance for operators' experience; oneunit change in operators' experience caused 0.19-unit change in SMEs performance. For management skill, one-unit change in management skill caused 0.14 -unit change in SMEs performance

Table 5. Regression Coefficients of Management success determinants and SMEs performance

\begin{tabular}{|c|c|c|c|c|c|c|c|c|}
\hline \multicolumn{9}{|c|}{ Coefficients $^{\mathrm{a}}$} \\
\hline \multirow{2}{*}{\multicolumn{2}{|c|}{ Model }} & \multicolumn{2}{|c|}{$\begin{array}{l}\text { Unstandardized } \\
\text { Coefficients }\end{array}$} & $\begin{array}{l}\text { Standardized } \\
\text { Coefficients }\end{array}$ & \multirow[t]{2}{*}{$\mathrm{T}$} & \multirow[t]{2}{*}{$\begin{array}{l}\text { Si } \\
\text { g. }\end{array}$} & \multicolumn{2}{|c|}{$\begin{array}{l}\text { Collinearity } \\
\text { Statistics }\end{array}$} \\
\hline & & B & $\begin{array}{l}\text { Std.Er } \\
\text { ror }\end{array}$ & Beta & & & $\begin{array}{l}\text { Tolera } \\
\text { nce }\end{array}$ & VIF \\
\hline \multirow[t]{2}{*}{1} & (Constant) & 7.92 & 1.44 & & 5.52 & .00 & & \\
\hline & Marketing & .43 & .09 & .10 & 4.53 & .00 & .71 & 1.41 \\
\hline
\end{tabular}




\begin{tabular}{|l|l|l|l|l|l|l|l|l|}
\hline Abilities & & & & & & & & \\
\hline $\begin{array}{l}\text { Management } \\
\text { Skill }\end{array}$ & .32 & .06 & .14 & 5.18 & .00 & .49 & 2.05 \\
\hline Innovation & .13 & .06 & .06 & 2.09 & .04 & .49 & 2.05 \\
\hline $\begin{array}{l}\text { Decision } \\
\text { Making } \\
\text { Process }\end{array}$ & .11 & .06 & .05 & 1.96 & .05 & .60 & 1.66 \\
\hline $\begin{array}{l}\text { Operating } \\
\text { System }\end{array}$ & .38 & .10 & .09 & 3.78 & .00 & .61 & 1.65 \\
\hline $\begin{array}{l}\text { Organisationa } \\
\text { Structure }\end{array}$ & .68 & .06 & .267 & 11.6 & .00 & .70 & 1.43 \\
\hline $\begin{array}{l}\text { Business } \\
\text { Reporting } \\
\text { System }\end{array}$ & .28 & .07 & .10 & 4.06 & .00 & .56 & 1.78 \\
\hline $\begin{array}{l}\text { System } \\
\text { Flexibility }\end{array}$ & .34 & .07 & .11 & 5.16 & .00 & .82 & 1.22 \\
\hline $\begin{array}{l}\text { Environmenta } \\
\text { Scanning } \\
\text { Practice }\end{array}$ & .48 & .10 & .12 & 4.98 & .00 & .65 & 1.54 \\
\hline a. Dependent Variable: SMEs Performance & & & & & \\
\hline
\end{tabular}

Source: Field Survey Results (2018).

$H_{4}$ : Management success determinants will have combined significant effects on SMEs performance in the selected Nigerian market environment.

Table 6 is the regression model summary of management success determinants and SMEs performance. It shows that a strong relationship exists between management success determinants and SMEs performance with $\mathrm{R}=0.80$, and that $63.90 \%$ variation in SMEs performance is caused by these management success determinants (adjusted $\mathrm{R}^{2}=0.64$ ) this effect is statistically significant.

Table 6: Regression Model Summary of Management success determinants and SMEs performance

\begin{tabular}{|c|c|c|c|c|c|c|c|}
\hline \multicolumn{6}{|c|}{ Model Summary } & \multirow[b]{2}{*}{$\mathrm{F}$} & \multirow[b]{2}{*}{$P$} \\
\hline Model & $\mathrm{R}$ & $\begin{array}{l}\mathrm{R} \\
\text { Square }\end{array}$ & $\begin{array}{l}\text { Adjusted } \\
\text { R Square }\end{array}$ & $\begin{array}{l}\text { Std. Error } \\
\text { of the } \\
\text { Estimate }\end{array}$ & $\begin{array}{l}\text { Durbin- } \\
\text { Watson }\end{array}$ & & \\
\hline 1 & $.80^{\mathrm{a}}$ & .64 & .64 & 4.12 & 1.88 & 174.93 & 0.00 \\
\hline \multicolumn{6}{|c|}{$\begin{array}{l}\text { a. Predictors: (Constant), Environmental Scanning, Marketing } \\
\text { Abilities, System Flexibility, Operating System, Organisational } \\
\text { Structure, Decision Making Process, Business Reporting System, } \\
\text { Management Skill, Innovation }\end{array}$} & & \\
\hline \multicolumn{6}{|c|}{ b. Dependent Variable: SMEs Performance } & & \\
\hline
\end{tabular}

Source: Field Survey Results (2018).

\section{Discussion of Results}

The findings show that a large percentage of the variations in SMEs performance are caused by management success determinants and the individual effects of management success determinants reveal that all have positive and significant 
effects on SMEs performance with the highest by organisational structure followed by operators' experience and management skills. All other management success determinants that also have positive and significant effects on SMEs performance are marketing abilities/skills, innovation, decision making process, operating systems, business reporting systems, system flexibility, and environmental scanning practices.

The results corroborate the resource-based view theory that stipulates that the growth of the firm is linked with its resources which are heterogonous and whose heterogeneity can be sustained overtime (Penrose, 1959). The ability to achieve and sustain a competitive advantage to produce better performance depends on whether such resources are of value, rare, imitable and non-substitutable. The management success determinants link with SMEs performance premised on the fact that as organisational resources, they have capacity to produce performance whose degree may vary in accordance to whether they are of value, rare, imitable and nonsubstitutable.

The results also corroborate the findings of several authors on the different management success determinants. For example Chang et al. (2018) linked marketing capability of world firms' brand with performance through the encouragement of customer value co-creation activities. Forth and Bryson (2019) established that management activities significantly affect the growth of a firm. Cardador and Pratt (2018) suggested that organizational practices should lead employees to identify with the customers.

Corroborating the findings of this research on the positive effects of innovation on SMEs performance is the work of Park and Shin (2017) who identified research and development capacity as the main determinants of technology innovations and related it with SMEs performance and that technological change, technological difficulty and gaps had positive effects on performance.

The findings of the positive effects of marketing and management skills on the performance of SMEs is also supported by Yayavaran and Chen (2015) and Wu and Chen (2014), they agreed that organization knowledge stock and skills often determine the degree of innovation performance. Such skills are noted to create internal and external coordination as well as effective teamwork and openness. Collings et al. (2019) established that management skills affect enterprise performance positively when they established a link between global talent management as a unit level human capital resource. Grewal et al. (2019) corroborated by establishing that marketing skills are critical for boosting consumers' self-esteem in such a way as to stimulate the purchase of unattractive products and thus reduce wastages (Gunders and Bloom, 2017; Liu et al., 2017). Connelly et al. (2018) asserted that management skills of competence and integritybased trust affect transaction costs in a company. Prifti and Alimehmeti (2017) and Turner and Hendry (2017) in separate studies also corroborated the findings of this 
study by stating that market orientation and innovation relate positively with SMEs performance and customer satisfaction while Acar et al. (2019) found that creative ideas generation and conversion into innovations is positively related to competitive advantage.

The work of Sharma et al. (2018) claimed that innovation achieved is based on the process adopted supported the researcher's findings on the positive effects of operating systems on SMEs' performance. Also, the works of Katsikeas et al. (2018) further align with the findings of this study when they established that a system of exploratory and exploitative learning facilitated firm sales performance. Martniaityle et al. (2019) advanced creativity orientated of high-performance work systems and Luciano et al. (2018) found that a multi team system (MTS) enhanced organizational performance.

Operators' experience also has a positive and significant effect on SMEs performance, this finding aligns with the findings of Heyden et al. (2018) who affirmed that management experience, educational qualification, age and gender moderate management innovation, also Whitler et al. (2018) established that experience of board members facilitates firm growth. Takeuchi et al. (2019) who established that workers with an abundant of work experience began with a high level of job performance and maintained the performance over the duration of international assignments. That worker with insufficient work experience often start with low level job experience and maintain it all through their international exposure.

Organizational structure also has positive and significant effect on SMEs performance, corroborating the study of Heyden et al. (2018) who also found that management structure, processes and practices improve organization, and Reiche et al. (2019) highlighted the need to satisfy a global customer through a veritable structure. The finding also align with the findings of Pertusa et al. (2018) who found that organizational structure has been found to relate to effective management of the environment showed that organizational design and structure influence the degree to which an organization can manage its environment and also affect the quality of management in such organization and hence performance.

\section{Managerial Implications}

The fact that management success determinants had positive and significant effects on the SMEs performance, causing close to seventy percent variations in performance implies that SMEs that will perform well must see to their marketing abilities/skills, innovation, decision making process, organizational structure, business reporting system, management skills, system flexibility and environmental scanning practice. However, significant attention must be given on system flexibility, organizational structure, management skill and environmental scanning practice. 
For management practice, one could infer that all the management success determinants are critical success factors of SMEs in Nigerian market environment. This is particularly instructive because Nigeria being an emerging economy needed to know the critical success factors that would make businesses to succeed in such environment. This is an important stepping knowledge for new entrants and failing firms more so past researches have it that about eighty five percent of small and medium scale enterprises in the country fail before their fifth anniversary.

\section{Recommendations}

The following recommendations are made based on the findings of this research:

- The significant difference in the evaluations of the management success determinants to performance by the operators show the degree of relevance of the different factors to their businesses, however it is important that each operator identifies which of the determinants is critical for his/her business so as to apportion resources and effective monitoring.

- The significant relationship between the management success determinants and SMEs performance shows that, management skills of the SMEs operators, organizational structure and innovation are the most critical success factors for the SMEs in Nigerian business environment. It is recommended that new entrants should develop their skills before entering the business through work experience and a formal structure of information flow and dissemination should be put in place, apart from creating enabling innovative environment devoid of bureaucratic system.

- The most significant individual effects are traceable to organizational structure, management skills and environmental scanning. It is imperative for the SMEs that hope to survive the Nigerian business environment to constantly scan the environment for information that could facilitate innovation apart from having a structured operational system and management skills.

- Institutionalizing the management success determinants through proper alignment to units and persons for effective monitoring is important in the light of the combined strong effects it has on the SMEs performance and high contribution to its variation. Adequate and effective management framework must be put in place by the firms to ensure this.

\section{Limitations and Future Research}

The first limitation is the restriction of the study to South West, Nigeria limits the generalization to the whole country and the close ended questions limits respondents elaborate expression of ideas. Despite these limitations the study made substantial contribution to the body of knowledge by building a model of the success factors of businesses in the South West, Nigeria with house majority of businesses in Nigeria. Further study can be conducted across all the six geopolitical regions of Nigeria, so 
as to provide comprehensive model for management success determinants and performance of SMEs in Nigeria.

\section{Conclusion}

This research examined the management success determinants and performance of Small and Medium scale Enterprises of South West, Nigeria. The findings revealed differences in the impact of the management success factors on the performance of the firms. All the management success determinants have relationships and effects on the performance of the small and medium scale enterprises. Organisational structure, management skills, environmental scanning and innovation proved to have the highest relationships/effects on the performance of small and medium scale enterprises. These have implications for new entrants into Nigerian business landscape as major factors to focus upon are concerned if success will be achieved. Recommendations and policy direction were further made.

\section{References:}

Acar, O.A., Tarakci, M., Van Knippenberg, D. 2019. Creativity and Innovation Under Constraints: A Cross-Disciplinary Integrative Review. Journal of Management 45(1), 96-121.

Adeola, A. 2016. Impact of external business environment on organisation performance of SMEs in Osun state, Nigeria. Scholedge International Journal of Business Policy and Governance, 3(10), 155-166.

Ahmed, A., Khuwaja, F.M., Brohi, N.A., Othman, I., Bin, I. 2018. Organizational Factors and Organizational Performance: A Resource-Based View and Social Exchange Theory Viewpoint. International Journal of Academic Research in Business and Social Sciences, 8(3), 579-599.

Akinbogun, T.L. 2008. The impact of Nigerian business environment on the survival of small-scale ceramic industries: Case study, South Western Nigeria. Journal of Asian and African Studies, 43(6), 663-679.

Akinruwa, T.E., Awolusi, O.D., Ibojo, B.O. 2013. Determinants of small and medium enterprises (SMEs) performance in Ekiti State, Nigeria: A business survey approach. European Journal of Humanities and Social Sciences, 27(1), 1390-1406.

Aminu, I.M., Shariff, M.N. 2015. Determinants of SMEs performance in Nigeria: A pilot study. Mediterranean journal of social sciences, 6(1), 156-164.

Arasa, R., K'Obonyo, P. 2012. The Relationship between Strategic Planning and Firm Performance. International Journal of Humanities and Social Science, 2(22), 201213.

Asikhia, O.U. (2010). SMEs and Poverty Alleviation in Nigeria: Marketing Resources and Capabilities Implications. New England Journal of Entrepreneurship, 13(2): 57-70.

Asikhia, O.U. (2016). SMEs' wealth creation model of an emerging economy. Eurasian Journal of Business and Economics 9(17): 125-151.

Bhattacherjee, A. 2012. Social Science Research: Principles, Methods and Practices, ( $2^{\text {nd }}$ Ed.) Florida: Global Text Project, Tampa, University of South Florida.

Bocconcelli, R., Cloppi, M., Fortezza, F., Francioni, B., Pagano, A., Savelli, E., Splendiani, S. 2018. SMEs and Marketing: A Systematic Literature Review. International Journal of Marketing Research, 20(2). 
Cardador, M.T., Pratt, M.G. 2018. Becoming Who we Serve: A Model of Multi-layered Employee-Customer Identification. Academy of Management Journal, 61(6), 20532080.

Chang, Y., Wang, X., Arnett, B.D. 2018. Enhancing firm performance: The role of brand orientation in Business-to-Business Marketing. Industrial Marketing Management. https://doc.org/10.1016/j.indmarman.2018.01.031.

Collings, D.G., Mellahi, K., Cascio, W.F. 2019. Global Talent Management and Performance in Multinational Enterprise: A Multilevel Perspective. Journal of Management, 45(2). 540-566.

Connelly, B.L., Crook, R., Combs, J.G. 2018. Competence and Integrity-Based Trust Interorganizational relationship: Which matters more? Journal of Management, 14(3), 419-432.

Cooper, D., Schindler, P. 2006. Business Research. New York, McGraw-Hill. https://trove.nla.gov.au/work/16067972.

Corporate Affairs Commission, CAC. 2017. Registration Dossier. Lagos, Macmillan.

Eniola, A.A., Entebang, H. 2015. Government policy and performance of small and medium business management. International Journal of Academic Research in Business and Social Sciences, 5(2), 237-248.

Fernando, A.C. 2011. Business environment. Dorling Kindersley India Pvt. Ltd. http://196.1.114.26/W27/Result/Dt1/W21OneItem.aspx?xC=013228.

Forth, J., Bryson, A. 2019. Management Practices and SMEs Performance. Journal of Political Economy, 66(4), 527-559.

Grewal, L., Hmurovic, J., Lamberton, C. 2019. The self-perception connection: why consumer devalue unattractive product. Journal of Marketing, 83(1), 89-107.

Gunders, D., Bloom, J. 2017. Wasted: How Amenza is losing up to 40 percent of its food from farm to fork to landfill. Report 17-05-A. New York, Natural Resources Defense council. https://www.nrdc.org/sites/default/files/wasted-food-IP.pdf.

Heyden, M.L.M., Sidhu, D.S., Volberda, H.W. 2018. The conjunct influence of top and model net characteristics on management innovation. Journal of Management, 44 (4), 1505-1529.

Ighodalo, G.J., Ugege, J.E., Omokhagbor, S. 2019. Investigation into the Use and Implementation of Business Plan in Ekpoma. Asian Journal of Business Management, 5(3), 326-331.

Katsikeas, C.S., Auh, S., Spyropoulou, S., Menguc, B. 2018. Unpacking the relationship between sales control and sale person performance: A regulatory fit perspective. Journal of Marketing, 82, 45-69.

Kothari, C.R. 2004. Research methodology: methods and techniques. New Delhi, New Age International Limited. https://trove.nla.gov.au/version/49040543.

Krecjie, R., Morgans, D. 1970. Determining sample size for research activities. Educational and Psychological Measurement, 30, 607-610.

Liu, U, Li, K.J., Chen, H.A., Balachauder, S. 2017. The effects of products Aesthetic design on demand and marketing mix effectiveness: The role of segment prototypicality and Brand consistency. Journal of Marketing, 81(1), 83-102.

Luciano, M.M., Dechurch, L.A., Mathieu, J.F. 2018. Multiteam systems: A structural framework andmeso- theory of system functioning. Journal of Management, 44(3), https://doi.org/10.1177/0149206315601184.

Maney, I.M., Manoloya, T.S., Harkins, J.A., Gyoshey, B.S. 2014. Are pure or hybrid strategies right for new ventures in transition economies? International Small Business Journal. doi:10.1177/0266242614550322. http://dx.doi.org/10.1177/0266242614550322. 
Martniaityle, L., Sacramento, C., Aryee, S. 2019. Delighting customer: Creativity oriented high performer work systems, frontline employee creative performance and customer satisfaction. Journal of Management, 45(2), 728-751.

Muritala, T.A., Awolaja, A.M., Bako, Y.A. 2012. Impact of Small and Medium Enterprises on Economic Growth and Development. American Journal of Business and Management, 1(1), 18-22.

Muthe, H.M., Aksoy, H. 2014. Strategic orientation, firm capabilities and export performance: An empirical analysis in Turkey. International Journal of Economic Practices and Theories, 4(2), 214-221.

Okwachi, S., Gakure, R., Ragui, M. 2013. Effect of Managerial Practices on the Implementation of Strategic Plans by SMEs in Nairobi, Kenya. European Journal of Business and Management, 5(13), 212-224.

Olabisi, S.Y., Olagbemi, A.A., Atere, A.A. 2011. Factors affecting small-scale business performance in informal economy in Lagos state-Nigeria: A gendered based analysis. Lagos, Lagos State University.

Olughor, R.J. 2015. Effect of innovation on the performance of SMEs organisations in Nigeria. Management, 5(3), 90-95. doi:http://doi.org/10.5923/j.mm.20150503.02.

Omar, C.M., Anas, T. 2014. E-commence in Malaysia: Development, implementation and challenges. International Review of Management and Business Research, 3(1), 291298.

Osamwonyi, I.O. 2010. The Nigerian Economy, Edo State Unemployment and the Role of Entrepreneurship. In: Osamwonyi, I.O. (ed) Training Manual For Participants of Graduate Entrepreneurial Scheme. Edo, Osatech Group Consulting.

Osamwonyi, I.O., Tafamel, A.E. 2010. Options for sustaining small and medium scale enterprises in Nigeria: emphasis on Edo State. African Research Review, 4(3), 192211.

Park, C., Shin, J. 2017. An exploratory study on the determinants of performance in regional industry technology development programs. Asia Pacific Journal of Innovation and Entrepreneurship, 11(2), 125-143.

Penrose, E. 1959. The theory of growth of the firm. New York, Wiley. https://global.oup.com/academic/product/the-theory-of-the-growth-of-the-firm9780199573844 ?cc $=$ us\&lang=en\&.

Pertusa-Ortega, E.M., Lopez-Gamero, M.D., Pereira-Moliner, J., Tari T., Molina, T. 2018. Antecedents of environment management: The influence of organizational Design and its mediating role between quality management and environmental management. Organization and Environment, 31(4), 425-443.

Prifti, R., Alimehmeti, G. 2017. Market orientation, innovation, and firm performance an analysis of Albanian firms. Journal of Innovation and Entrepreneurship, 6(8). doi:http://doi.org/10.1186/s13731-017-0069-9.

Reiche, B.S, Lee, Y., Allen, D.G. 2019. Actors structure and processes: A received and conceptualization of Global work interesting IB and HRM Research. Journal of Management, 45(2), 359-383.

Rizan, M., Balfas, F., Purwohedi, U. 2019. The Influence of Strategic Orientation, Organizational Innovation Capabilities and Strategic Planning on the Performance of Technology-based Firms. Academy of Strategic Management Journal, 18(31), 111.

Sabli, H.M., Latiff, H.A. 2019. Interactions among Factors Affecting Micro-Entrepreneur Performance in Sarawak, Malaysia. International Journal of Academic Research in Business and Social Sciences, 9(3), 208-218.

Serrasqueiro, Z., Leitao, J., Smallbone, D. 2018. Small and Medium-sized Enterprises 
(SMEs) Growth and Financing Sources: Before and After the Financial Crisis. Cambridge: Cambridge University Press. Doi: http://dx.doi.org/10.1017/jmo.2018.14.

Sharma, A., Saboo, A.R., and Kumar, V. 2018. Investigating the Influence of Characteristics of the New Product Introduction Process on Firm Value: The Case of the Pharmaceutical Industry. Journal of Marketing, 82(5), 66-85.

Small and Medium Enterprise Development Agency of Nigeria. 2012. Survey report on MSMEs in Nigeria. Abuja, SMEDAN.

Small and Medium Enterprise Development Agency of Nigeria. 2016. Survey report on MSMEs in Nigeria. Abuja, SMEDAN.

Small and Medium Enterprise Development Agency of Nigeria. 2017. Survey report on MSMEs in Nigeria. Abuja, SMEDAN.

Takeuchi, R, Li, Y., Wang, M. 2019. Expatriates' performance Profiles: Examining the effect of work experience on the longitudinal change patterns. Journal of Management, 45 (2), 451-475.

Turner, T., Henry, S. 2017. Radical innovation and value extraction: the role of the user's entrepreneurial passion on satisfaction with product, firm, and industry. Journal of Small Business and Entrepreneurship, 29(2), 156-173.

Van Scheers, L. 2011. SMEs' marketing skills challenges in South Africa. African Journal of Business Management, 5(13), 5048-5056.

Wang, S., Zhou, X. 2019. New insights into Organization Structure and Business Process: An Integrative Point of View. Open Journal of Business and Management, 7(4), 1953-1961.

Whitler, K.A., Krause, R.V., Lehman, D.R. 2018. When and how boards with marketing experience facilitate firm growth. Journal of Marketing, 82(5), 85-105.

Wu, I., Chen, J. 2014. Knowledge management driven firm performance: the roles of business process capabilities and organisational learning. Journal of Knowledge Management, 18, 1141-1164.

Yayavarans, Y., Chen, W. 2015. Change in firm knowledge couplings and firm innovation performance: The moderating role of technological complexity. Strategic Management Journal, 36, 377-396. 